Agro-Science Journal of Tropical Agriculture, Food, Environment and Extension Volume 10 Number 3 September 2011 pp $1-12$

ISSN 1119-7455

\title{
NITROLIMEGATION: A NUTRIENT-IN-WATER RESOURCE FOR SUSTAINABLE CROP PRODUCTION ON 'ACID SANDS' OF SOUTHERN NIGERIA
}

\author{
Amalu U. C. and Okon P. B. \\ Department of Soil Science, University of Calabar, P.M.B. 1115, Calabar, Nigeria
}

\begin{abstract}
:
The effects of a low-external-input soil fertility enhancement solution - hereafter termed 'nitrolimegation' were investigated as a more convenient strategy for application of nitrogen and calcium in the "Acid Sands" soils of south-eastern Nigeria. Two types of nitrogenous fertilizer sources [Urea and liquid pig manure (LPM)] and two types of lime [limestone-CaCO${ }_{3}$ and slake lime-Ca $\left.(\mathrm{OH})_{2}\right]$ were employed variously at the following levels: Urea $\left[\mathrm{CO}\left(\mathrm{NH}_{2}\right)_{2}\right] \mathrm{0}, 40,50,80,100$, 120 , and $150 \mathrm{~kg} / \mathrm{ha}$; lime $0,0.1,0.3,0.5,1.0,5.0$, and 10.0 metric tonnes per hectare (t/ha) and LPM 0, 30, 60, 90 and 120 t/ha, arranged factorially and laid out in randomized complete block design (RCBD). The results indicated that combining lime at 9 t/ha and LPM at 90 t//ha in irrigation water had significant $(P<0.01)$ positive effects on the soil fertility status and growth of the test crop (Okra-Abelmoschus esculentus). When urea combined with slake lime, it offset acidity and provided nutrient balance in the Acid Sands of Calabar; total nitrogen was significantly $(P<0.01)$ boosted from 0.05 to $0.11 \%$, base saturation (BS) from 46 to $62 \%$ and exchange acidity was reduced from 2.93 to $1.35 \mathrm{cmol} / \mathrm{kg}$. Combining urea (46-0-0) at $80 \mathrm{~kg} / \mathrm{ha}$ with lime $\left(\mathrm{CaCO}_{3}\right)$ at $5 \mathrm{t} / \mathrm{ha}$ raised the soil $\mathrm{pH}$ from 4.4 to 7.1 . Exchange acidity was reduced from $0.8 \mathrm{cmol} / \mathrm{kg}$ to negligible value but electrical conductivity was improved from 170.7 to $291.9 \mu \mathrm{S} / \mathrm{cm}$. When $L P M$ and lime were combined, organic carbon was increased from 2.75 to $2.93 \%$, BS was increased from 46.72 to 75.19 $\%$, and $\mathrm{pH}$ was raised from 6.0 to 6.73 . Plant height was increased from 9.5 to $16.9 \mathrm{~cm}$ while mean number of leaves was also increased from 5.6 to 6.3 only with lower level of lime (3 t/ha) and LPM at $90 \mathrm{t} / \mathrm{ha}$. Of the nitrogen and calcium sources, LPM and limestone $y$ were better at 120 t/ha and 9 t/ha, respectively, to offset soil acidity, boost nutrient availability and provide balanced supply to arable crops grown on the Acid Sands.
\end{abstract}

Keywords: Nitrolimegation, Nitrogen fertilizer, Liming, Liquid pig manure, Acid Sands, Okra (Abelmoschus esculentus L. Moench).

\section{INTRODUCTION}

Nitrolimegation is a soil fertilization technique which involves the dissolution of a nitrogenous fertilizer and good grade lime in irrigation water, and the application of the resulting solution to soils for crop use. The resulting solution could be delivered in drip/trickle irrigation system, or drenched into the soil. It is a new agro-technique developed to rehabilitate highly leached acid sandy soils for sustainable production of arable and vegetable crops. Application of a solution of urea and lime, in irrigation is a good example of nitrolimegation, because both are mixable, easily soluble in water and hardly precipitates (Burt, 2011).

Nitrogen is a potent nutrient element that should not only be conserved but carefully regulated. Promising sources of water soluble nitrogen are urea, sodium nitrate $\left(\mathrm{NaNO}_{3}\right)$, calcium nitrate, organic manure and anhydrous ammonia. These $\mathrm{N}$-sources are soluble in water at $20{ }^{\circ} \mathrm{C}$ and potently raises soil $\mathrm{pH}$. They are therefore safer for the acid sand soils. Other sources have the tendency of further lowering the soil $\mathrm{pH}$, hence should be avoided (Burt, 2011; Lenntech, 2011). Urea can readily undergo hydrolysis in the soil, producing ammonium carbonate as follows:

$\mathrm{CO}\left(\mathrm{NH}_{2}\right)_{2}+2 \mathrm{H}_{2} \mathrm{O} \longrightarrow\left(\mathrm{NH}_{4}\right)_{2} \mathrm{CO}_{3} \ldots \ldots$ (Eqn. 1 Although the immediate effect of this fertilizer is towards alkalinity, and its residual influence tends to lower soil $\mathrm{pH}$, the ammonium carbonate produced is ideal for rapid nitrification, especially if exchangeable bases are present in adequate amounts (Brady and Weil, 1999). In cultivated soils, nitrogen (N) element is subject to continual loss, via nutrient removal 
in harvested plant, erosion, leaching and volatilization. Utilization of $\mathrm{N}$ by crop plants is indispensable in most instances but losses caused by volatilization, erosion, and leaching constitute a serious wastage of vital nutrient resource. Losses of $\mathrm{N}$ by leaching occur mainly as $\mathrm{NO}_{3}-\mathrm{N}$ because of the low capacity of most soils to retain it. There is also a potential for $\mathrm{N}$ to be leached wherever rainfall or water supply regularly exceeds evapotranspiration, and significant leaching losses have been reported in some cropping systems (Theocharopoulos et al., 1993).

Most studies on use of livestock wastes for agricultural purposes deal with cattle and poultry droppings in manuring crop plants and their manurial values have been confirmed for many crops (Tel and Rao, 1992). Information on manurial value of pig manure slurries is replete in the temperate agricultural literature. The slurries were found to improve soil physical properties and nutrients status (Royer et al., 2003; Chartigyn et al., 2004). The fertilizing value of pig manure (pig dung) in crop production has however received little attention in tropical countries. In Nigeria, for example, large quantities of this material are dumped at disposal sites, especially in the southern and middle belt areas of Nigeria (Olomilua et al., 2007). In the scanty literature on the lowly fertile soils of south-east Nigeria, pig manure was also found to improve soil chemical properties (Mbagwu et al., 1994; Brechin and McDonald, 1994) and yield of maize (Okpara and Mbagwu, 2003).

In Nigeria, acid sand covers about 17 million hectares of land and acidity is common in all regions where precipitation is high enough to leach appreciable amount of exchangeable bases from the soils, leading to associated problems of aluminium toxicity, low nutrient status, nutrient imbalances and multiple nutrient deficiencies (Sanchez et al., 1997). The southern Cross River State soils, formed from coastal plain sands parent materials have been known to be acidic in nature. This is due to the vulnerability of the soils around the area to leaching and erosion resulting in high levels of hydrogen ions $\left(\mathrm{H}^{+}\right)$, aluminium ions $\left(\mathrm{Al}^{3+}\right)$ and sulphur in the soil, thus causing soil acidity and loss of soil nutrients in large proportions (Enwezor, et al., 1989; Okon et al., 2005). As a soil amendment strategy, adding free calcium $\left(\mathrm{Ca}^{+}\right)$to irrigation water either from native soil lime or calcium compound like limestone have been a practice that readily improves infiltration, while reducing the effects of excess $\mathrm{Na}^{+}, \mathrm{H}^{+}$or $\mathrm{Al}^{3+}$ in the soils (Anon, 2011).

With the foregoing background, investigations involving a greenhouse pot experiment and two field trials, were carried out to determine the effects of urea and lime, on one hand, and liquid pig manure and hydrated lime on the other; on selected properties of Ultisols and the growth of okra (Abelmoschus esculentus L. Moench), an important tropical and subtropical vegetable, as a test crop.

\section{MATERIALS AND METHODS}

One greenhouse and two field experiments were conducted at Teaching and Research Farm, Faculty of Agriculture, University of Calabar, Nigeria [Lat $04^{\circ} 56^{\prime} \mathrm{N}$; Long. $008^{\circ} 21^{\prime} \mathrm{E}$ ] (GPS, 2007). The greenhouse experiment was conducted in the year 2007 while the field experiments followed in 2008 and 2010. The study area falls under the tropical wet-humid zone. Mean annual temperatures of the study area ranged from 25 to $33{ }^{\circ} \mathrm{C}$, while mean annual rainfall amounts ranged from 2725 to $3500 \mathrm{~mm}$ (Alabi \& Ibiyemi, 2000). The rainy season occurs between April and November, while dry season starts in November and lasts through March, though it's gradually changing due to climate change effects. The experiments were conducted during the growing season beginning at the onset of rains in order to measure the impact of the treatments on the porous sandy soil of the area.

The soils of Calabar are mainly Coastal Plain Soils: taxonomically classified as Ultisols (Typic Paleudults) (Esu, 2005), or Ferralitic soils (Enwezor et al., 1989). The soils are highly leached because of high infiltration rates, but also subjected to water erosion. Because of the dominance of sesquioxides, and low activity clay and organic matter contents, the soils are generally sandy and acidic.

Land use of the area include cultivation of arable crops (cassava, cocoyam, yams, pepper, maize), vegetables (fluted pumpkin, cucumber, okra, water leaf, pumpkin, melon), etc. On a wider scale, commercial pineapple and tree crops such as oil palm, rubber, gmelina plantations have been established in the area.Soil Sampling and laboratory analyses: Prior to planting, one composite soil sample each was collected at depths of 0 to $15 \mathrm{~cm}$ (top soil) and 15 to $30 \mathrm{~cm}$ (sub soil) for laboratory analysis. After each experiment, soil samples were again taken from each treatment plot for analysis. The numbers of samples were determined by the number of treatment plots in the year of study. Soil samples were air-dried, ground, and passed through $2.00 \mathrm{~mm}$ and $0.21 \mathrm{~mm}$ sieves, and the physicochemical properties were determined using routine methods described in the IITA (IITA, 1979) and Udo et al. (2009) laboratory manuals. Soil reaction was determined in a solution (1:2 soil: water ratio) and the $\mathrm{pH}$ read in 
a calomel glass electrode $\mathrm{pH}$ meter. Organic carbon (OC) was determined by the Walkley and Black wet-oxidation method described by Nelson and Sommers (1996) and soil organic matter (SOM) was estimated by multiplication with the Van Bemmelen factor of 1.724. Some exchangeable cations $\left(\mathrm{Ca}^{2+}, \mathrm{Mg}^{+}\right.$and $\left.\mathrm{Na}^{+}\right)$were determined spectrophotometrically after extraction with appropriate reagents. But potassium $\left(\mathrm{K}^{+}\right)$concentration was determined with a flame photometer. Available phosphorus was determined by the Bray P 1 method as outlined by Udo et al. (2009). Effective cation exchange capacity (ECEC) was obtained by summing up the exchangeable cations, including exchange acidity, which was the summation of hydrogen ions $\left(\mathrm{H}^{+}\right)$and aluminium ions $\left(\mathrm{Al}^{3+}\right)$. Base saturation was obtained using equation 2;

Base saturation $(\%)=\left(\frac{T E B}{E C E C}\right) x 100 \ldots$ Eqn. (2)

Where: $\mathrm{TEB}=$ total exchangeable bases (sum of $\mathrm{Ca}, \mathrm{Mg}, \mathrm{K}, \mathrm{Na}$ ) and $\mathrm{ECEC}=$ effective cations exchange capacity (sum of $\mathrm{Ca}, \mathrm{Mg}, \mathrm{K}, \mathrm{Na}, \mathrm{H}$, $\mathrm{Al})$.

Cylindrical cores measuring $5.8 \mathrm{~cm}$ high and $5.5 \mathrm{~cm}$ wide were used to take samples for bulk density determinations as described by Blake and Hartge (1986). Total porosity was calculated from bulk density and particle density data using the formula in equation

$$
T_{p}=\left(1-\frac{\rho_{b}}{\rho_{\mathrm{p}}}\right) \times 100
$$

where $T p=$ total porosity $(\%), \rho_{b}=$ bulk density and $\rho_{\mathrm{p}}=$ particle density. Particle density was assumed to be $2650 \mathrm{~kg} \mathrm{~m}^{-3}$ as given by Danielson and Sutherland (1986) for many mineral soils.

Preparation of Nitrolime - the Nutrient-inwater Solutions (for 2007, 2008 and 2010) and Nitrolimegation as a process:

Nitrolimegaton: Applicable dosages of urea and lime were dissolved in $50 \mathrm{ml}$ of water in small containers and drenched into the soil. Drenching involves opening a small hole in the soil and the solution injected, to avoid volatilization of the nutrient. Fifty $(50 \mathrm{ml})$ of the pre-mixed solution was drenched into the soil fortnightly for 4 months before the soil is sampled for laboratory analysis. However, it has been reported that injecting the nutrient carriers through irrigation water is typically more expensive than soil applications, as it requires high-grade product and special injection equipment (Anon, 2011).

Greenhouse Trials (2007):

In the greenhouse experiment which commenced in 2007, six kilograms of air-dried, manually sifted top soils were put into each of some forty-eight perforated plastic pots and laid out in the University Teaching \& Research Greenhouse. Four levels [0, 0.1, 0.2 and $0.3 \mathrm{t} / \mathrm{ha}$ ] of hydrated lime $\left[\mathrm{Ca}(\mathrm{OH})_{2}\right]$ and four levels $[0$, 40,80 , and $120 \mathrm{~kg} / \mathrm{ha}$ ] of urea [CO $\left(\mathrm{NH}_{2}\right) ; 46-0$ 0 ] were combined in a $4 \times 4$ factorial, diluted in $600 \mathrm{ml}$ of water and poured into the pots arranged in Completely Randomized Design (CRD) three days prior to sowing with okra as test crop. The sixteen treatment combinations were formulated and applied every two weeks up to the fourth month of the five-month trial.

Experimental materials and Plots layout for Field

Trials (2007, 2008 and 2010):

Experimental materials were urea, liquid pig manure (LPM), hydrated lime, limestone, and okra Abelmoscus esculentus L. Moench - the Calabar local dwarf okra variety. The liming rate used were $0,3,6,9$ t/ha and LPM rates $0,30,60,90,120 \mathrm{t} / \mathrm{ha}$. The treatments were combined in a 4 x 5 factorial and arranged in a Randomized Complete Block Design (RCBD). The treatments were replicated thrice, giving 3 blocks, each consisting of 20 treatment units. A total of sixty treatments were laid out on sunken beds measuring $2 \mathrm{~m} \mathrm{x} 1 \mathrm{~m}$. Furrows of $0.5 \mathrm{~m}$ were allowed in-between the beds and a furrow of $3 \mathrm{~m}$ in-between the blocks. Immediately following the greenhouse trials, field trials were also commenced in 2007 with treatments involving varying combinations of slaked lime rates $(0.0,0.1,0.5$ and 1.0 tonnes/ha) and urea rates $(0,50,100,150 \mathrm{~kg} / \mathrm{ha})$. Okra remained the test crop. In the 2008 experiment, the source of lime was changed to limestone $\left(\mathrm{CaCO}_{3}\right)$, a readily available local resource. Various rates $(0,5,10$ tonnes/ha) of limestone were combined with urea (NPK: 46-0-0) rates of 0,60 and $90 \mathrm{~kg} \mathrm{~N} / \mathrm{ha}$ and the resulting solutions drenched into the raised beds and monitored for 16 weeks. Lime rates were computed according to the RothLime® Calculator (2002) equation, using initial soil reaction $(\mathrm{pH})$ and texture as inputs in the model. The field trials were followed up two years later, in 2010, with a change only of the source of nitrogen: urea, an inorganic source was replaced with Liquid Pig Manure (LPM), another readily available local organic $\mathrm{N}$ resource. LPM was prepared right in the field by dissolving the solid pig dung in water in a drum, stirring the suspension and allowing it to settle for at least 6 hours and the solid matter discarded. Thereafter, the 
supernatant solution is properly mixed and scooped out into smaller basins at rates equivalent of $0,30,60,90$ and 120 tonnes/ha. In turn, pre-determined lime rates of $0,3,6$, and 9 tonnes/ha were added to the appropriate basins and re-mixed. These 5 by 4 factorial combinations were laid out in the field in a randomized complete block design (RCBD) and same test crop, okra, planted.Plant Data Collection: Two days after the application of the treatments the test crop was sown at $30 \mathrm{~cm}$ by 20 $\mathrm{cm}$ spacings, with two seeds per stand. One month after planting, plant height and number of leaves were taken at weekly intervals for twelve weeks.

Samples and data Analyses: Samples for soil $\mathrm{pH}$ measurements were taken for laboratory analysis on weekly basis. At the end of the field experiment whole-field soil sampling was repeated in each treatment unit and samples analysed again for determination of the effect of the treatment combination on the soil physical and chemical properties. The liming rates used in these experiments were determined using the Rothamsted Lime Requirement Model (Rothlime $\subset$, 2002). The data obtained from the experiments were subjected to analysis of variance and other statistical analyses using the GenStat (2007) discovery edition analytical software. Regression and correlation analyses were done with the IBM-SPSS ${ }^{\circledR}$ version 19 software, however.

Table 1 shows some properties of the well cultivated soil used for the experiment. The top soils were sandy loam, while the sub-soils were sandy clay loam. The particle density of the soils were $2.39 \mathrm{~g} \mathrm{~cm}^{-3}$ and $2.56 \mathrm{~g} \mathrm{~cm}^{-3}$ for top-soil and sub-soil layers respectively, values somewhat lower than the standard mineral soil particle density of $2.65 \mathrm{~g} \mathrm{~cm}^{-3}$ (Danielson and Southerland, 1986). The bulk densities of these soils were 1.43 , and $1.3 \mathrm{~g} \mathrm{~cm}^{-3}$ for top-soil and sub-soil respectively. According to Brady and Weil (1999), the bulk densities of clay, clay loam, and silt loam surface normally range from 1.00 to $1.60 \mathrm{~g} \mathrm{~cm}^{-3}$ depending on their condition. A variation from 1.20 to $1.80 \mathrm{~g} \mathrm{~cm}^{-3}$ may be found in sands and sandy loam. The soils were mildly acid in reaction ( $\mathrm{pH} 4.8$ to 5.1 ), poor in organic carbon, but very moderately endowed with available soil phosphorus. Total nitrogen and exchangeable bases levels were low to moderate, while exchangeable hydrogen and aluminium were moderate, corroborating the acid soil conditions, and low base saturation percents, despite moderate effective CEC valu

\section{RESULTS}

(A) Effects of nitrolime on some properties of soils at the end of the trialse Greenhouse trials: The nutrient-in-water solution influenced some chemical properties of the soils in different ways: whereas total nitrogen (TN) contents and base saturation percentage were enhanced, from 0.05 to $0.11 \%(\mathrm{P}<0.01)$ and 46.1 to $62.1 \%$ respectively, exchangeable acidity was reduced from 2.93 to $1.35 \mathrm{cmol} / \mathrm{kg}$ (Table 2). With over $50 \%$ reduction in the acidity under greenhouse conditions, it was considered that remarkable percentage reduction even if not up to $50 \%$ could also be achieved under field conditions, and the crops may have better growth and development with lower exchangeable hydrogen $\left(\mathrm{H}^{+}\right)$and aluminium $\left(\mathrm{Al}^{3+}\right)$ ions in the rhizosphere. In the "acid sand" soils exchangeable acidity, especially of excess aluminium, can constitute a major constraint to soil productivity. For most plant species the obvious effects of excess $\mathrm{Al}^{3+}$ are swollen, stunted and crooked and there are few feeder roots. A high $\mathrm{Al}^{3+}$ concentration in the soil solution thus prevents plants from utilizing soil water and nutrients efficiently. In the plant, free $\mathrm{Al}^{3+}$ binds strongly to the phosphate groups in nuleic acids, so inhibiting cell division, affects phosphokinase and ATPase activity and often inhibits $\mathrm{P}$ uptake and translocation (Von Uexkull, 1986). Aluminium toxicity may, depending on the relative amounts and availability of plant nutrients, manifest itself in plants as $\mathrm{Mn}$ and fe toxicities and $\mathrm{Ca}$ or $\mathrm{Mg}$ deficiencies. The ultimate goal of lowering exchangeable acidity was the premise for the field trials that followed the greenhouse investigations. Field trials (2007): The results (Tables 3 and 4) indicated negative response to $\mathrm{TN}$ over time as it significantly $(\mathrm{P}<0.05)$ decreased from 0.13 to $0.10 \%$ in the control. Lime did not have any effect as applied dosages were not sufficient to elicit any reasonable response. Instead of increases, there were some decreases in the soil parameters compared to the control in this experiment. The result of 2007 field experiments showed decrease in the exchangeable acidity of the soil so treated with the nitrolime solution. The exchangeable acidity dropped from $2.99 \mathrm{cmol} \mathrm{kg}^{-1}$ in control to 2.19 $\mathrm{cmol} \mathrm{kg}^{-1}$ after 12 weeks. When $5.0 \mathrm{t} / \mathrm{ha}$ of lime and $90 \mathrm{~kg} / \mathrm{ha}$ of urea was applied, there was remarkable decrease in exchangeable acidity of the soil from $0.2 \mathrm{cmol} \mathrm{kg}^{-1}$ to $0.0 \mathrm{cmol} \mathrm{kg}^{-1}$; this observation progressed as liming and nitrogen fertilizer rates were increased and enough time was allowed for the treatments to integrate with the native soil solution.

Field trials (2008): The results (Table 5 ) indicated that sole lime at $5 \mathrm{t} / \mathrm{ha}$ raised the soil 
$\mathrm{pH}$ from 5.34 to 7.03 while sole urea treatment raised the soil $\mathrm{pH}$ to 6.40 . However, one might wonder if urea contains any active ingredient that can knock off soil acidity, but some guidelines (Anon, 2011) indicated that application of some soil amendments can trigger some chemical reactions in the soil which then enable native soil lime to be broken down and free $\mathrm{Ca}^{+}$released, this can have a concomitant effect of improving the soil reaction. In a related work on tropical Ultisols, Asiegbu and Agba (2008) observed improved percentage pod-set after just eight weeks of applying lime and phosphorus in water; soil $\mathrm{pH}$ was rapidly increased from 4.91 to 6.05 with only $2 t \mathrm{CaCO}_{3}$ $\mathrm{ha}^{-1}$. The combined effect of lime and urea respectively at $5 \mathrm{t} / \mathrm{ha}$ and $60 \mathrm{~kg} / \mathrm{ha}$ raised the soil $\mathrm{pH}$ from initial level of 4.4 to 7.10 . Exchangeable acidity was reduced from 0.8 $\mathrm{cmol} / \mathrm{kg}$ to zero. But electrical conductivity (EC) was improved from 170.7 in the control to 291.9 $\mu \mathrm{S} / \mathrm{cm}$ in the plot treated with $10 \mathrm{t} / \mathrm{ha}$ of lime. For emphasis, Fig 1 shows the interactive effects of lime $\left[\mathrm{Ca}(\mathrm{OH})_{2}\right]$ and urea $\left[\mathrm{Co}\left(\mathrm{NH}_{2}\right)_{2}\right]$ on the soil's electrical conductivity; lime at $10 \mathrm{t} \mathrm{ha}^{-1}$ and urea at $60 \mathrm{~kg} \mathrm{ha}^{-1}$ moved the EC up to 400 $\mu \mathrm{S} / \mathrm{cm}$ and proved to be the best combination for improvement of EC in the coastal plain soils.

Figure for Nitrolimigation Paper

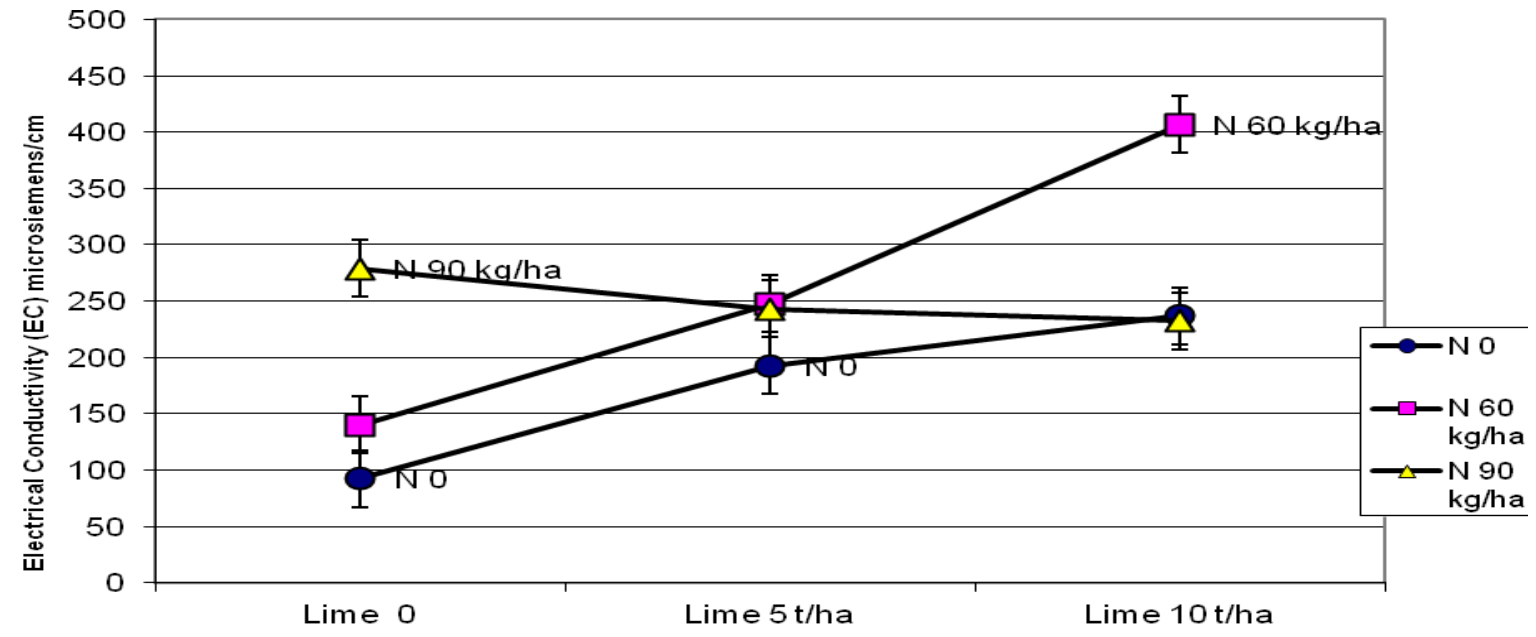

Fig. 1: Interactive effect of the NitroLime solution on soil electrical conductivity in 2008 Error bars indicate interaction $L S D_{0} \cap=25.16$

Table 1: Analysis of the soil before commencing the experiments in 2007 and 2010

\begin{tabular}{lccccc}
\hline \multicolumn{1}{c}{ Parameter } & Unit & $\begin{array}{c}\mathbf{2 0 0 7} \\
\text { Top soil }\end{array}$ & $\begin{array}{c}\mathbf{2 0 0 7} \\
\text { Sub-soil }\end{array}$ & $\begin{array}{c}\mathbf{2 0 1 0} \\
\text { Top Soil }\end{array}$ & $\begin{array}{c}\text { S010 } \\
\text { Sub-soil }\end{array}$ \\
\hline Sand & $\mathrm{g} \mathrm{kg}^{-1}$ & 769 & 796 & 767 & 717 \\
Silt & $\mathrm{g} \mathrm{kg}^{-1}$ & 74 & 47 & 60 & 50 \\
Clay & $\mathrm{g} \mathrm{kg}^{-1}$ & 157 & 157 & 173 & 233 \\
Textural class & & $\mathrm{SL}$ & $\mathrm{SL}$ & $\mathrm{SL}$ & $\mathrm{SCL}$ \\
Particle density & $\mathrm{g} / \mathrm{cm}^{3}$ & $(2.65)$ & $(2.65)$ & 2.39 & 2.56 \\
Bulk density & $\mathrm{g} / \mathrm{cm}^{3}$ & 1.42 & 1.52 & 1.43 & 1.3 \\
Organic carbon & $\mathrm{g} \mathrm{kg}^{-1}$ & 1.41 & 1.28 & 4.31 & 3.65 \\
Soil pH (1:25 soil: water ratio) & & 5.04 & 4.78 & 4.8 & 5.1 \\
Available phosphorus & $\mathrm{mg} / \mathrm{kg}^{-1}$ & 45.8 & 54.7 & 73 & 56 \\
Total nitrogen & $\mathrm{g} \mathrm{kg}{ }^{-1}$ & 01.2 & 01.1 & 03.3 & 03.0 \\
Exchangeable bases & & & & & \\
Ca & $\mathrm{cmol} / \mathrm{kg}$ & 1.4 & 1.4 & 1.6 & 1.6 \\
$\mathrm{Mg}$ & $\mathrm{cmol} / \mathrm{kg}$ & 1.0 & 0.8 & 2.8 & 3.4 \\
$\mathrm{Na}$ & $\mathrm{cmol} / \mathrm{kg}$ & 0.08 & 0.09 & 0.07 & 0.07 \\
$\mathrm{~K}$ & $\mathrm{cmol} / \mathrm{kg}$ & 0.07 & 0.11 & 0.09 & 0.10 \\
Exchangeable acidity & & & & & \\
$\mathrm{Al} l^{++}$ & $\mathrm{cmol} / \mathrm{kg}$ & 1.56 & 2.08 & 8.6 & 9.2 \\
$\mathrm{H}^{+}$ & $\mathrm{cmol} / \mathrm{kg}$ & 0.60 & 0.72 & 12.4 & 14 \\
Effective CEC & $\mathrm{cmol} / \mathrm{kg}$ & 4.71 & 5.20 & 25.56 & 28.37 \\
Base Saturation & $\%$ & 54.1 & 46.2 & 17.8 & 18.2 \\
\hline
\end{tabular}

Values in brackets are standard tropical values for mineral soils. 
A Nutrient-In-Water Resource for Sustainable Crop Production

Table 2: Effects of nitrolime solution on some chemical properties of soils in the greenhouse trials

\begin{tabular}{llllllll}
\hline $\begin{array}{l}\text { Nitrogen (Urea) Trt. } \\
\left(\mathrm{kg} \mathrm{N} \mathrm{ha}^{-1}\right)\end{array}$ & $\begin{array}{l}\text { Soil } \\
\mathrm{pH}\end{array}$ & $\begin{array}{l}\text { Total N } \\
(\%)\end{array}$ & $\begin{array}{l}\text { ECEC } \\
\left.(\mathrm{cmol} \mathrm{kg})^{-1}\right)\end{array}$ & $\begin{array}{l}\text { EA } \\
\left(\mathrm{cmol} \mathrm{kg}^{-1}\right)\end{array}$ & $\begin{array}{l}\text { T.E.B. } \\
\left(\mathrm{cmol} \mathrm{kg}^{-1}\right)\end{array}$ & $\begin{array}{l}\text { EC } \\
\left(\mathrm{cmol} \mathrm{kg}^{-1}\right)\end{array}$ & $\begin{array}{l}\text { BS } \\
\left(\mathrm{cmol} \mathrm{kg}^{-1}\right)\end{array}$ \\
\hline Control =0 & 4.65 & 0.05 & 9.16 & 2.95 & 6.24 & 0.81 & 67.46 \\
$\mathrm{~N} 1=40$ & 5.08 & 0.07 & 7.35 & 2.25 & 5.10 & 0.66 & 69.41 \\
$\mathrm{~N} 2=80$ & 5.05 & 0.09 & 8.18 & 1.78 & 6.41 & 0.75 & 77.77 \\
$\mathrm{~N} 3=120$ & 5.13 & 0.11 & 7.00 & 1.35 & 5.65 & 0.69 & 80.41 \\
Lime Treatment (kg ha & & & & & & & \\
\hline Control = & 5.05 & 0.07 & 7.06 & 1.68 & 5.38 & 0.32 & 75.40 \\
L1 $=100$ & 4.88 & 0.07 & 7.31 & 1.98 & 5.33 & 0.48 & 73.17 \\
L2 $=200$ & 4.78 & 0.08 & 8.39 & 2.23 & 6.16 & 0.95 & 73.09 \\
L3 $=300$ & 5.20 & 0.08 & 8.95 & 2.43 & 6.52 & 1.16 & 73.39 \\
Sig level (Nitrogen) & $\mathrm{NS}$ & $\mathrm{P}<0.01$ & $\mathrm{NS}$ & $\mathrm{P}<0.01$ & $\mathrm{NS}$ & $\mathrm{NS}$ & $\mathrm{P}<0.01$ \\
Sig level (Lime) & $\mathrm{NS}$ & $\mathrm{P}<0.01$ & $\mathrm{NS}$ & $\mathrm{P}<0.01$ & $\mathrm{NS}$ & $\mathrm{P}<0.01$ & $\mathrm{NS}$ \\
\hline
\end{tabular}

$\mathrm{NS}=$ no significant difference

Table 3: Changes in soil reaction, electrical conductivity and exchangeable acidity in response to nitrolime treatments over time

\begin{tabular}{|c|c|c|c|c|c|c|c|c|}
\hline $\begin{array}{l}\text { Treatment } \\
(\mathrm{kg} / \mathrm{ha})\end{array}$ & Soil Parameter & Wk 0 & Wk 2 & Wk 4 & Wk 6 & Wk 8 & Wk 10 & Wk 12 \\
\hline Control & Soil pH & 5.10 & 5.00 & 4.83 & 4.23 & 4.17 & 4.13 & 4.27 \\
\hline Lime $=0$ & $\mathrm{EA}(\mathrm{cmol} / \mathrm{kg})$ & 2.99 & 2.09 & 2.16 & 2.16 & 2.08 & 2.10 & 2.19 \\
\hline Urea $=0$ & $\mathrm{EC}(\mu \mathrm{S} / \mathrm{cm})$ & 87.7 & 119.6 & 125.7 & 140.7 & 165.8 & 180.3 & 197.3 \\
\hline \multirow{3}{*}{$\begin{array}{l}\text { Lime }=5000 \\
\text { Urea }=90\end{array}$} & Soil pH & 6.10 & 7.77 & 7.43 & 7.30 & 6.63 & 7.20 & 6.70 \\
\hline & $\mathrm{EA}(\mathrm{cmol} / \mathrm{kg})$ & 0.20 & 0.16 & 0.03 & 0.10 & 0.00 & 0.00 & 0.00 \\
\hline & $\mathrm{EC}(\mu \mathrm{S} / \mathrm{cm})$ & 207.3 & 215.4 & 211.8 & 209.6 & 252.3 & 270.7 & 278.7 \\
\hline \multirow{3}{*}{$\begin{array}{l}\text { Lime }=10000 \\
\text { Urea }=90\end{array}$} & Soil pH & 6.77 & 7.53 & 6.80 & 653 & 6.67 & 6.53 & 6.83 \\
\hline & $\mathrm{EA}(\mathrm{cmol} / \mathrm{kg})$ & 0.24 & 0.03 & 0.03 & 0.16 & 0.00 & 0.08 & 0.00 \\
\hline & $\mathrm{EC}(\mu \mathrm{S} / \mathrm{cm})$ & 249.7 & 240.5 & 217.8 & 261.5 & 241.7 & 221.6 & 215.0 \\
\hline
\end{tabular}

Table 4: Changes in soil total nitrogen, exchangeable calcium and base saturation percentage in response to nitrolime treatments over time.

\begin{tabular}{|c|c|c|c|}
\hline $\begin{array}{l}\text { Treatment } \\
(\mathrm{kg} / \mathrm{ha})\end{array}$ & Soil Parameter & Wk 0 & Wk 12 \\
\hline Control & Total N (\%) & 0.13 & 0.10 \\
\hline Urea $=0$ & BS (\%) & 70.0 & 79.0 \\
\hline \multirow{2}{*}{$\begin{array}{l}\text { Lime }=5000 \\
\text { Urea }=90\end{array}$} & Total N (\%) & 0.19 & 0.16 \\
\hline & $\mathrm{Ca}(\mathrm{cmol} / \mathrm{kg})$ & 2.8 & 5.6 \\
\hline \multirow{3}{*}{$\begin{array}{l}\text { Lime }=10000 \\
\text { Urea }=90\end{array}$} & Total N (\%) & 0.11 & 0.19 \\
\hline & $\mathrm{Ca}(\mathrm{cmol} / \mathrm{kg})$ & 3.2 & 5.7 \\
\hline & $\mathrm{BS}(\%)$ & 80.5 & 84.9 \\
\hline
\end{tabular}

The parameters in this table were not monitored weekly, rather at inception and termination of the trials. 
Electrical conductivity increased as the rate of lime and urea increased while exchangeable acidity decreased tremendously and knocked off acidity to zero. The nitrogen material applied to the soil at $60 \mathrm{~kg} / \mathrm{ha}$ raised the soil $\mathrm{pH}$ from 6.03 in the control to 6.61 which can promote plant growth and development, and this agrees with Muoneke (1999) observation that application of nitrogen base fertilizer to crops promotes plant growth and development. Same $60 \mathrm{~kg} / \mathrm{ha}$ of nitrogen improved the soil electrical conductivity from $173.9 \mu \mathrm{s} / \mathrm{cm}$ to $264.8 \mu \mathrm{S} / \mathrm{cm}$

(Table 3). On the other hand, lime that was applied to the soil at the rate of $10 \mathrm{t} \mathrm{ha}^{-1}$ raised the soil $\mathrm{pH}$ significantly from 5.34 in the control to 7.03. The $\mathrm{pH}$ of 7.03 presents a near neutral soil reaction in which most soil nutrients are readily available for plant uptake (Brady and Weil, 1999). The liming material also improved the electrical conductivity from $170.61 \mu \mathrm{S} / \mathrm{cm}$ to $291.90 \mu \mathrm{S} / \mathrm{cm}$ showing that increment in liming material increases soil electrical conductivity and reduces soil exchangeable acidity hereby making the soil favourable for plant growth and nutrient uptake. As time progressed, there was significant decrease in exchangeable acidity (EA) from $0.24 \mu \mathrm{s} / \mathrm{cm}$ to $0.08 \mu \mathrm{s} / \mathrm{cm}$. Also there was corresponding increase in the value of electrical conductivity (EC) from $211.5 \mu \mathrm{s} / \mathrm{cm}$ in the first week of the experiment to $248.7 \mu$ $\mathrm{S} / \mathrm{cm}$. The changes were not concomitant with changes in soil $\mathrm{pH}$ over time, rather soil $\mathrm{pH}$ responded positively to changes in the treatment levels rather than time. This demonstrates that popular belief on elongated trials for lime to react on soil can be abridged by solubilising it in

Table 5: Effects of nitrolime on soil pH, electrical conductivity and exchangeable acidity in 2008.

\begin{tabular}{llll}
\hline $\begin{array}{l}\text { Treatment } \\
\text { Lime (kg/ha) }\end{array}$ & Soil pH & $\begin{array}{l}\text { Electrical Conductivity } \\
(\mu \mathrm{S} / \mathrm{cm})\end{array}$ & $\begin{array}{l}\text { Exchangeable Acidity } \\
(\mathrm{cmol} / \mathrm{kg})\end{array}$ \\
\hline Control & $5,34^{\mathrm{c}}$ & $170.7^{\mathrm{c}}$ & $0.466^{\mathrm{a}}$ \\
5000 & $6.67^{\mathrm{b}}$ & $227.8^{\mathrm{b}}$ & $0.022^{\mathrm{b}}$ \\
10000 & $7.03^{\mathrm{a}}$ & $291.8^{\mathrm{a}}$ & $0.006^{\mathrm{c}}$ \\
$L S D_{0.05}$ lime & 0.140 & 41.74 & 0.0925 \\
Urea (kg/ha) & & & $0.285^{\mathrm{a}}$ \\
Control & $6.03^{\mathrm{c}}$ & $174.0^{\mathrm{C}}$ & $0.109^{\mathrm{b}}$ \\
60 & $6.61^{\mathrm{a}}$ & $264.8^{\mathrm{a}}$ & $0.100^{\mathrm{c}}$ \\
90 & $6.40^{\mathrm{b}}$ & $251.5^{\mathrm{b}}$ & 0.165 \\
Grand mean & 6.35 & 230.1 & 6.0925 \\
$L S D_{0.05}($ Urea $)$ & 0.140 & 14.52 & \\
\hline
\end{tabular}

Mean followed by different alphabets were significantly $(\mathrm{P}<0.05)$ different at $5 \%$ level of probability.

Table 6: Effect of lime on soil chemical properties (post-experiment)

\begin{tabular}{|c|c|c|c|c|c|c|c|c|c|}
\hline \multirow{2}{*}{$\begin{array}{c}\text { Treatment } \\
\text { Lime (t/ha) }\end{array}$} & \multirow{2}{*}{$\begin{array}{c}\text { Soil } \\
\mathrm{pH}\end{array}$} & \multirow{2}{*}{$\begin{array}{c}\text { Total } \\
\text { nitrogen } \\
(\%)\end{array}$} & \multirow{2}{*}{$\begin{array}{c}\text { Organic } \\
\text { carbon }(\%)\end{array}$} & \multirow{2}{*}{$\begin{array}{c}\text { Available } \\
\text { phosphorus } \\
(\mathrm{mg} / \mathrm{kg})\end{array}$} & \multicolumn{3}{|c|}{ Exchangeable bases $(\mathrm{cmol} / \mathrm{kg})$} & \multirow{2}{*}{$\begin{array}{c}\text { ECEC } \\
(\mathrm{cmol} / \mathrm{kg})\end{array}$} & \multirow{2}{*}{$\begin{array}{c}\text { Base } \\
\text { saturation } \\
(\%)\end{array}$} \\
\hline & & & & & $\mathrm{Ca}$ & $\mathrm{Mg}$ & $\mathrm{K}$ & & \\
\hline 0 & 5.84 & 0.32 & $2.75^{\mathrm{c}}$ & $57^{\mathrm{d}}$ & $1.96^{\mathrm{d}}$ & $1.00^{\mathrm{d}}$ & 0.090 & 6.73 & $46.72^{d}$ \\
\hline 3 & 6.62 & 0.33 & $2.89^{\mathrm{b}}$ & $65^{\mathrm{b}}$ & $2.32^{\mathrm{c}}$ & $2.48^{\mathrm{a}}$ & 0.110 & 7.59 & $65.61^{\mathrm{b}}$ \\
\hline 6 & 6.72 & 0.34 & $2.74^{\mathrm{d}}$ & $59^{\mathrm{c}}$ & $2.84^{\mathrm{b}}$ & $1.36^{\mathrm{c}}$ & 0.098 & 7.07 & $62.39^{\mathrm{c}}$ \\
\hline 9 & 6.92 & 0.34 & $2.93^{\mathrm{a}}$ & $70^{\mathrm{a}}$ & $3.32^{\mathrm{a}}$ & $2.16^{\mathrm{b}}$ & 0.112 & 7.58 & $75.19^{\mathrm{a}}$ \\
\hline $\mathrm{LSD}_{0.01}$ & $\begin{array}{c}0.64 \\
8\end{array}$ & 0.42 & 0.93 & $9.538 * *$ & $0.184 * *$ & 0.948 & 0.31 & 0.97 & $0.34 * *$ \\
\hline
\end{tabular}


.irrigation water thereby releasing the potent electrolytes readily to react with the soil electrolytic system. This readily neutralises the soil reaction instead of waiting on the long queue for rainwater to solubilise the lime before it can react.

Field trials (2010): The results indicated that the best levels of lime and LPM to be mixed in the irrigation water were $9 \mathrm{t} / \mathrm{ha}$ and $120 \mathrm{t} / \mathrm{ha}$ respectively. Applying the solution at this combined rate increased organic carbon content significantly $(\mathrm{P}<0.05)$ from the initial of 2.75 to $2.93 \%$, soil $\mathrm{pH}$ was moved from 6.0 to 6.73, which falls in the safest range for cultivation of most arable crops. Base saturation was increased from 46.7 to $75.2 \%$; Available phosphorus (Bray 1 method) was increased from 57 to $70 \mathrm{mg} / \mathrm{kg}$ showing surplus availability

Table 6 shows the effect of lime on some chemical properties. The lime, when applied sole, raised the soil $\mathrm{pH}$ from 5.84 in the control to 6.92 at the rate of $9 \mathrm{t} / \mathrm{ha}$ lime, this can promote plant growth and development and agrees with Muoneke, (1999) which stated that application of nitrogen-based fertilizer to crop (e.g. okra) promoted the plant growth and development. Nitrogen content in the control was $0.32 \%$, which was increased to $0.34 \%$ when $6 \mathrm{t} / \mathrm{ha}$ of lime was applied. However, there was no significant difference. Available phosphorus

significantly $(\mathrm{P}<0.05)$ increased from $57 \mathrm{mg} / \mathrm{kg}$ in the control to $70 \mathrm{mg} / \mathrm{kg}$ when $9 \mathrm{t} / \mathrm{ha}$ of lime was applied. Also, exchangeable calcium was increased significantly $(\mathrm{P}<0.05)$ from $1.96 \mathrm{cmol}$ $\mathrm{kg}^{-1}$ when no lime was applied to $3.32 \mathrm{cmol} / \mathrm{kg}$ when $9 \mathrm{t} / \mathrm{ha}$ of lime was applied. There were some significant $(\mathrm{P}<0.05)$ improvements in some soil fertility indicators when $9 \mathrm{t} / \mathrm{ha}$ of lime was applied to the soil. This tonnage had significant $(\mathrm{P}<0.05)$ change on the base saturation status of the soil as it rose from 46.72 $\%$ in the control to $75.19 \%$.

Table 7 shows the effects of sole LPM application on some soil chemical properties. The LPM raised the soil $\mathrm{pH}$ from 6.02 in the control to 6.73 when $120 \mathrm{t} / \mathrm{ha}$ of liquid pig manure was applied. Total nitrogen content in the soil was raised from $0.33 \%$ when no LPM was applied to $0.36 \%$ when 120 t/ha of LPM was applied. Available phosphorus increased significantly $(\mathrm{P}<0.01)$ from $55 \mathrm{~m} / \mathrm{kg}$ in the control to $68 \mathrm{mg} / \mathrm{kg}$ when $90 \mathrm{t} \mathrm{ha}^{-1}$ of LPM applied. Also, exchangeable $\mathrm{Ca}$ increased from $2.05 \mathrm{cmol} / \mathrm{kg}$ when no LPM was applied to 2.95 $\mathrm{cmol} / \mathrm{kg}$ when $90 \mathrm{t} / \mathrm{ha}$ of LPM was applied. Most of the effects on LPM on soil chemical properties are presented in Table 4. On the other hand, effective CEC decreased significantly from $8.09 \mathrm{cmol} / \mathrm{kg}$ to $6.77 \mathrm{cmol} / \mathrm{kg}$ when $30 \mathrm{t} / \mathrm{ha}$ LPM was applied, while base saturation increased significantly from $54.82 \%$ to $69.42 \%$ when 60 t/ha was applied (Table 6). Effects of Nitrolimigation on growth parameters of test crop (Okra)

From the ANOVA of 2007 results, there were no statistically significant differences in the fresh fruit yield and number of pods of the okra plant. In 2010, applying nitrolime at the soils' best levels of $9 \mathrm{t} \mathrm{ha}^{-1}$ of lime and $120 \mathrm{t} \mathrm{ha}^{-1}$ of LPM through the irrigation water had some effects on the test crop; the plant height was increased from $9.5 \mathrm{~cm}$ to $16.9 \mathrm{~cm}$ but not significantly different from application of nitrolime at lower rates. On other parameters, mean number of leaves increased from 5.6 to 6.3 with reduced combination of the lime and LPM at $3 \mathrm{tha}^{-1}$ and $90 \mathrm{t} \mathrm{ha}^{-1}$ respectively.

The results in Table 8 showed that when solubilized lime alone was applied to the soil it increased plants height and number of leaves. The plant height was increased from 9.00 $\mathrm{cm}$ in the control to $17.67 \mathrm{~cm}$ at the rate of $6 \mathrm{t}$ $\mathrm{ha}^{-1}$. Lime, at this rate, enabled soil nutrients to be readily available for plant uptake, which in turn has a positive effect on the height of the plants. Also, the number of leaves increased significantly from 5.01 in control to 6.69 with 6 $\mathrm{t} / \mathrm{ha}$ of lime, showing that increment in liming material increased plant height and number of leaves, but where the lime is applied at the rate of $9 \mathrm{t} / \mathrm{ha}$ it reduced the plant height and number of leaves but insignificantly. There were significant differences in both plant height and number of leaves when 6 t/ha of lime was applied.

Table 7: Effect of LPM on soil chemical properties (post-experiment)

\begin{tabular}{|c|c|c|c|c|c|c|c|c|c|}
\hline \multirow{2}{*}{$\begin{array}{c}\text { Treatmen } \\
\text { t LPM } \\
\text { (t/ha) }\end{array}$} & \multirow[t]{2}{*}{ Soil pH } & \multirow{2}{*}{$\begin{array}{c}\text { Total } \\
\text { nitrogen }(\%)\end{array}$} & \multirow{2}{*}{$\begin{array}{c}\text { Organic } \\
\text { carbon }(\%)\end{array}$} & \multirow{2}{*}{$\begin{array}{c}\text { Available } \\
\text { phosphorus } \\
(\mathrm{m} / \mathrm{kg})\end{array}$} & \multicolumn{3}{|c|}{ Exchangeable bases $(\mathrm{cmol} / \mathrm{kg})$} & \multirow{2}{*}{$\begin{array}{c}\text { ECEC } \\
(\mathrm{cmol} / \mathrm{k} \\
\mathrm{g})\end{array}$} & \multirow{2}{*}{$\begin{array}{c}\text { Base } \\
\text { saturation } \\
(\%)\end{array}$} \\
\hline & & & & & $\mathrm{Ca}$ & $\mathrm{Mg}$ & $\mathrm{K}$ & & \\
\hline 0 & 6.03 & 0.325 & 2.840 & $53^{\mathrm{e}}$ & $2.05^{\mathrm{e}}$ & 2.15 & 0.097 & 8.093 & 54.82 \\
\hline 30 & 6.50 & 0.335 & 2.800 & $66^{\mathrm{c}}$ & $2.01^{\mathrm{d}}$ & 1.55 & 0.097 & 6.770 & 55.25 \\
\hline 60 & 6.68 & 0.315 & 2.850 & $64^{\mathrm{d}}$ & $2.15^{\mathrm{c}}$ & 2.15 & 0.112 & 7.875 & 69.42 \\
\hline 90 & 6.70 & 0.327 & 2.875 & $68 \mathrm{a}$ & $2.95^{\mathrm{a}}$ & 2.95 & 0.100 & 6.825 & 63.96 \\
\hline 120 & 6.73 & 0.357 & 2.765 & $67^{b}$ & $2.80^{\mathrm{b}}$ & 2.80 & 0.105 & 6.660 & 68.95 \\
\hline $\mathrm{LSD}_{0.01}$ & 0.73 & 0.97 & 0.14 & $0.732 * *$ & $0.513 * *$ & 0.748 & 0.019 & 0.140 & 0.092 \\
\hline
\end{tabular}

Mean followed by different alphabets were significantly $(\mathrm{P}<0.01)$ different at $1 \%$ level of probability. 
Table 8: Effect of sole lime treatment on plant height and number of leaves

\begin{tabular}{ccc}
\hline & \multicolumn{2}{c}{ Parameter } \\
\cline { 2 - 3 } Treatment: lime (t/ha) & Plant height $(\mathrm{cm})$ & No. of leaves \\
\hline 0 & $9.00^{\mathrm{b}}$ & $5.01^{\mathrm{b}}$ \\
3 & $15.39^{\mathrm{a}}$ & $6.28^{\mathrm{a}}$ \\
6 & $17.67^{\mathrm{a}}$ & $6.69^{\mathrm{a}}$ \\
9 & $15.91^{\mathrm{a}}$ & $6.43^{\mathrm{a}}$ \\
Grand mean & 14.49 & 6.10 \\
S.E.D. & 1.099 & 0.319 \\
$L S D_{0.01}$ & $2.232^{* *}$ & $0.648^{* *}$ \\
\hline
\end{tabular}

Mean followed by different alphabets were significantly $(\mathrm{P}<0.01)$ different at $1 \%$ level of probability.

$\mathrm{SED}=$ standard errors of differences of means. $\mathrm{LSD}=$ Fisher's least significant difference.

Table 9: Effect of LPM on plants height and number of leaves

\begin{tabular}{ccc}
\hline & \multicolumn{3}{c}{ Parameter } \\
\cline { 2 - 3 } Treatment LPM (t/ha) & Plant height $(\mathrm{cm})$ & No. of leaves \\
\cline { 2 - 3 } & $9.51^{\mathrm{c}}$ & $5.64^{\mathrm{b}}$ \\
30 & $14.39^{\mathrm{b}}$ & $6.31^{\mathrm{a}}$ \\
60 & $14.68^{\mathrm{b}}$ & $5.90^{\mathrm{b}}$ \\
90 & $16.87^{\mathrm{a}}$ & $6.34^{\mathrm{a}}$ \\
120 & $17.01^{\mathrm{a}}$ & $6.31^{\mathrm{a}}$ \\
Grand Mean & 14.49 & 6.10 \\
SED & 1.099 & 0.319 \\
$L S D_{0.05}$ & $2.232^{* *}$ & $0.648^{* *}$ \\
\hline Means followed by different alphabets were significantly $(\mathrm{P}<0.01)$ different at $1 \%$ level of probability.
\end{tabular}

Table 10: Interactive effects of lime and LPM on plant height and number of leaves

\begin{tabular}{|c|c|c|c|}
\hline \multicolumn{2}{|c|}{ Treatment } & \multicolumn{2}{|c|}{ Parameter } \\
\hline Lime (t/ha) & $\begin{array}{l}\text { LPM } \\
(\mathrm{t} / \mathrm{ha})\end{array}$ & $\begin{array}{l}\text { Plant height } \\
(\mathrm{cm})\end{array}$ & No. of leaves \\
\hline \multirow{2}{*}{ Control } & $\overline{0}$ & $(4.51)$ & $(5.00)$ \\
\hline & 30 & 9.84 & 5.54 \\
\hline \multirow[t]{5}{*}{0} & 60 & 6.03 & 3.85 \\
\hline & 90 & 11.76 & 5.70 \\
\hline & 120 & 13.33 & 5.39 \\
\hline & 0 & 16.44 & 5.67 \\
\hline & 30 & 15.92 & 7.08 \\
\hline \multirow[t]{5}{*}{3} & 60 & 15.69 & 6.42 \\
\hline & 90 & 16.89 & 5.88 \\
\hline & 120 & 18.04 & 6.34 \\
\hline & 0 & 11.33 & 6.34 \\
\hline & 30 & 16.47 & 6.42 \\
\hline \multirow[t]{5}{*}{6} & 60 & 18.73 & 6.63 \\
\hline & 90 & 21.44 & 7.17 \\
\hline & 120 & 20.38 & 6.92 \\
\hline & 0 & 21.27 & 6.02 \\
\hline & 30 & 15.34 & 6.21 \\
\hline \multirow[t]{3}{*}{9} & 60 & 18.26 & 6.71 \\
\hline & 90 & 17.40 & 6.63 \\
\hline & 120 & 16.31 & 6.60 \\
\hline \multicolumn{2}{|c|}{ Grand Mean } & 14.49 & 6.10 \\
\hline \multicolumn{2}{|c|}{ SED } & 2.459 & 0.714 \\
\hline \multicolumn{2}{|c|}{$\mathrm{LSD}_{0.01}$} & 4.991 (NS) & 1.449 (NS) \\
\hline
\end{tabular}

Mean followed by different alphabets were significantly $(\mathrm{P}<0.01)$ different at $1 \%$ level of probability. Values

in braces indicate the initial soil condition before treatments were applied. 
Table 9 shows that when LPM was applied to the soil as sole treatment, significant effects were observed in plant height. The test crop height was increased from $9.5 \mathrm{~cm}$ in the control to $16.8 \mathrm{~cm}$ at $90 \mathrm{t} \mathrm{ha}^{-1}$ of LPM. On the other hand, the number of leaves increased significantly $(\mathrm{P}<0.01)$ from 5.6 in the control to 6.3 with same LPM treatment level. Olomilua et al. (2007) in their work concluded that LPM at the rate of $100 \mathrm{t} / \mathrm{ha}$ is preferable for the cultivation of okra for both height and number of leaves. This result showed that LPM at $90 \mathrm{t} \mathrm{ha}^{-1}$ gives maximum number of leaves in the plant, but when the LPM is further increased to 120 $\mathrm{t} / \mathrm{ha}$ the number of leaves is reduced while in plant height increased insignificantly.

Table 10 shows the general effects of LPM and lime on plant height and number of leaves. In number of leaves, the leaves increased from 4.3 to 9.38 when only LPM was added at $60 \mathrm{~kg} / \mathrm{ha}$. Yet, the results of analysis of variance indicated no significant differences in the means.

\section{DISCUSSIONS}

This study revealed that the treatment of irrigation water with the nitrolime solution had pronounced effects on the acidic Coastal Plain Soils of Calabar. There were significant $(\mathrm{P}<0.05)$ increases in soil reaction from 5.3 at control to 7.02 when 10 t/ha of lime was added in irrigation water and applied to the soil (Table 6). Also, in combination with the organic $\mathrm{N}$ source (LPM), there were significant effects on the soil with resultant $\mathrm{pH}$ of 6.92 when lime at a rate of $9 \mathrm{t} \mathrm{ha}^{-1}$ was applied from initial $\mathrm{pH}$ of 4.8 . Liquid Pig Manure (LPM) as sole treatment showed significant effect on the soil reaction by pushing it up to 6.73 at the rate of $120 \mathrm{t} \mathrm{ha}^{-1}$. Earlier studies (Akande et al., 2005) in which nitrogen and liming materials were applied separately and not also in solution form took longer time for the anticipated reaction to occur. The importance of nitrogen cannot be underestimated; Asadi et al. (2002) recorded that besides increasing yield, nitrogen is a key nutrient in the formation and building up of essential amino acids in plants which are basic to all kinds of life functions. Acid soils of this tropical coastal area have shown this great potential for improvement when treated with adequate doses of soil additives like urea, organic nitrogen and lime, and acts readily when dissolved in irrigation water. These additives are capable of stabilizing soil reactions, availability of essential nutrients and improving cation exchange capacity (CEC). This study had shown that application of lime helps in reducing soil acidity, and much more rapidly when the lime is made soluble for quick reaction with the soil electrolytes. On the other hand, there was gradual increase in the level of electrical conductivity from mean of $177.7 \mu \mathrm{S} / \mathrm{cm}$ at control to a mean of $291.8 \mu \mathrm{s} / \mathrm{cm}$ when lime at 10 t/ha was applied (Fig. 1). This electrical conductivity indicated that though the treatment materials were combined, their impacts were independent and it did have contrasting effects on the soil properties and consequently the crops that could be grown on them. It could thus be suggested that the treatment of irrigation water with 'nitrolime' can be a panacea for increasing the fertility and productivity status of the poor and acid sandy soil $\mathrm{pH}$ Calabar in southern Nigeria. Based on the result, for decrease in soil acidity and optimum crop growth and productivity, the application of $9 \mathrm{t} / \mathrm{ha}$ of lime and $90 \mathrm{t} / \mathrm{ha}$ of liquid pig manure had so far been observed as the best treatment for Calabar "Acid Sand" soils.

\section{CONCLUSIONS}

From the results of this experiment, it was concluded that lime and LPM in irrigation water (nitrolimegation) is a potential panacea that could both offset soil acidity and provide nutrient balance in acid sandy soils of Southern Nigeria based on significant effects of the lime at $9 \mathrm{t} \mathrm{ha}^{-1}$, and LPM at $90 \mathrm{t} \mathrm{ha}^{-1}$. The interaction between the lime and LPM on "Acid Sands" of Calabar are capable of stabilizing soil reactions, improving effective cation exchange capacity, base saturation and availability of essential nutrients. Some schools of thought working on lime, had propounded that it takes a very long time ( $\geq 6$ months) for lime to react in the soil, but that could be applicable only when powdery lime is broadcasted or incorporated in the soil. In this study, it has been demonstrated that when lime is solubilised in irrigation water, it releases ammonium carbonate during hydrolysis (Eqn. 1). This tends to attack most of the free acid radicals available in soil solution and lowers the acid potentials of the soil. This research also demonstrated that application of lime in liquid form reduces soil acidity from strongly acid condition, before the treatments, to a near neutral condition, after the treatments, within a reasonably short period of time. These observations were tested over a period of three years even with varying treatment materials having same active ingredients.

\section{ACKNOWLEDGEMENTS:}

The authors are grateful to the following exstudents of ours that helped in carrying out the field work (2006-2010) to establish the concept of nitrolimegation: Ekarika, Emem S; Emone, Sandra O; Assam, Agnes N; and Udo, Imaobong E. 


\section{REFERENCES:}

Akande, M. D., Oluwatonyinbo, F. I., Adediran, J. A. 2005. Response of okra (Abelmoschus esculentus) to lime and phosphorus fertilization in acid soil. World Journal of Agricultural Science (2): $178-183$

Alabi, R. T. and Ibiyemi, A. G. 2000. Rainfall in Nigeria and food crop production. In: Agronomy in Nigeria. Dept. of Agronomy, University of Ibadan, Ibadan. Pp.63 - 66.

Asadi, M. E., Clemente, R. S., Gupta, A. D., Loof, R., Hansen, G. K. 2002. Impacts of fertigation via sprinkler irrigation on nitrate leaching and corn yield in an acid-sulphate soil in Thailand. Agricultural Water Management 52: $197-213$.

Asiegbu, J. E. and Agba, O. A. 2008. Studies on yield and yield component responses of Mucuna flagellipes to lime and phosphorus applications under field culture in a tropical Ultisols. Journal of Tropical Agriculture, Food, Environment and Extension Vol. 7 (1): $58-65$.

Anonymous. 2011. Soil \& Water Notes: Soil amendments to improve infiltration. Fruit and Nut Research \& Information Center, University of California, Davis. Accessed on 21 December 2011, Available online at http://fruitsandnuts.ucdavis.edu/SoilWa ter/Soil_Amendments

Blake, G. R., and Hartge, K. H. 1986. Bulk density (core method). In: Methods of Soil Analysis, Part 1 - Physical and Mineralogical Methods, Second Edition, Klute A. (Editor). Soil Science Society of America, Inc., Madison, Wisconsin. Chapter 13; p. 363 - 375.

Brady, N. C. and Well, R. R. 1999. The nature and properties of soils. $12^{\text {th }}$ Ed. Prentice Hall Inc. New Jersey.

Brechin, J. and McDonald, G. K. 1994. Effect of form and rate of pig manure on the growth nutrient uptake and yield of barley. Australian Journal Exp. Agric. 34: $505-510$.

Burt, Charles M. 2011. Chemicals for fertigation. Proceedings of international irrigation show.I A's $19^{\text {th }}$ Annual Conference. Nov. 1-8, 1998, San Diego, CA. Irrigation Association Annual Conference. ITRC paper 98002. Accessed online on December 29, 2011 http://www.itrc.org/papers/fertig/chemi calsforfertigation.pdf

Chartigyn, M. H., Angers, D. A. Moruan, T. and Pomer, C. 2004. Dynamics of pig slurry nitrogen in soil and plants as determined with $\mathrm{N}{ }^{15}$. Soil Science Society of America Journal, 68, 637 643.

Danielson, R. E. and Sutherland, P. L . 1986. Porosity. In: Methods of Soil Analysis, Part 1, Physical and Mineralogical methods - Agronomy Monograph no. 9 ( $2^{\text {nd }}$ edition). American Society of Agronomy, Madison, WI 53711, USA; pp. $433-461$.

Enwezor, W. O., Udo, E. J., Usoro, N. J., Ayotade, K. A., Adepotu, J. A., Chude, V. O., Udegbe, C. I. 1989. Fertilizer use and management practices for crops in Nigeria (Series No. 2). FPPD, Federal Ministry of Agriculture, Water Resources and Rural Development, Lagos.

Esu, Ivara E. 2005. Characterization, classification and management problems of the major Soil Orders in Nigeria. $26^{\text {th }}$ Inaugural Lecture of the University of Calabar delivered on April 26, 2005. Calabar, Nigeria: University of Calabar.

GenStat $^{\circledR}$, 2007. General Statistics Software Release 7.2 Discovery Edition. Herts, UK: Lawes Agricultural Trust (Rothamsted Experiment Station)/VSN International Ltd. Available online at: http://discovery.genstat.co.uk/

GPS. 2007. Global Positioning System data obtained at the farm site with Magellan Meridian ${ }^{\circledR}$ GPS in October 2007.

International Institute of Tropical Agriculture (IITA). 1979. Selected Methods for Soil and Plant Analysis, Manual Series No.1. IITA, Ibadan, Nigeria.

Lenntech. 2011. Nitrogen and water: reaction mechanisms, environmental impacts and health effects. LennTech B.V, Italy. Accessed online the internet http://www.lenntech.com/periodic/wate r/nitrogen/nitrogenandwater/ on 23 December 2011.

Mbagwu, J. S. C.; Unamba-Okapara, I. and Neuoh, G. O. 1994. Physicochemical properties and productivity of two tropical soils amended with dehydrate swine wastes. Bioresource Tech. 49, $163-171$.

Muoneke, I. B. 1999. Okra vegetable production. An aui book published by Van Nostrand Rein hold New Jersey. 
Nelson, D. W., and Sommers, L. E. 1996. Total carbon, organic carbon and organic matter. In: Methods of Soil Analysis, Part 3 - Chemical Methods. D. L. Sparks et al. (Eds). Madison, Wisconsin: Soil Science Society of America, Inc. Chapter 34; p 961 1010.

Okon, P. B., Ogeh, J. S. and Amalu, U. C. 2005. Effect of rice husk ash and phosphorus on some properties of Acid Sands and yield of okra.

Communications in Soil Science and Plant Analysis Vol. 36, No 7 \& 8: 833-845.

Okpara, M. and Mbagwu, J. S. C. 2003. Effectiveness of cattle dung and swine waste as biofertilizer on an Ultisol at Nsukka. Proceeding $28^{\text {th }}$ Annual Conference Soil Science Society of Nigeria, Umudike, $4^{\text {th }}$ November. P. 71 -80 .

Olomilua, A. I., Akanbi, O. S. O. and Ojeniyi, S. O. 2007. Effects of pig manure on nutrient composition, growth and yield of okra. Department of Crop, Soil and Pest Management, Federal University of Technology, Akure, Ondo State.
Rothamsted Experimental Station 2002. Rothlime(C): The Rothamsted Lime Requirement Model. Constructed by K. Goulding et al. and programmed by Paul McGrath (2002). Rothamsted Experimental Station, UK.

Royer, I., Simarrd, R. R., Bermnett, G. M. Cluisx, D. and Angers, D. A. 2003. Long term effects of liquid pig manure on the phosphorus status of a silty loam cropped to com. Canadian J. Soil Science. 83, $589-600$.

Sanchez, P. A., Stover, E. R., and Push Prarajah 1997. Management of acid tropical soils for sustainable agriculture. Proceedings of IBB RAM Inaugural workshop. Bangkok Thailand. Pp. 107.

Tel, D. A. and Rao, P. 1992. Automated and semi automated method for soil \& plant analysis. Manual series No. 7 IITA Ibadan.

Udo, E. J.; T. O. Ibia; J. A. Ogunwale; A. O. Ano; and I. E. Esu. 2009. Manual of soil, plant, and water analyses. Sibon Books Ltd., Lagos. 183pp. 